TAHKIM, Jurnal Peradaban dan Hukum Islam. Vol.3 No.2 (0ktober, 2020) | ISSN : $2597-7962$

\title{
IMPLEMENTASI HUKUM WARIS PADA MASYARAKAT ADAT MANDAILING PERANTAUAN (STUDI PADA PARDOMUAN MUSLIM SUMATERA UTARA KOTA PALANGKA RAYA)
}

\author{
Nia Kurniati Hasibuan \\ Fakultas Ekonomi dan Bisnis Islam IAIN Palangka Raya \\ nia.kurniati.hasibuan@iain-palangkaraya.ac.id
}

\begin{abstract}
ABSTRAK
Implementasi hukum waris adat di Indonesia sangat bergantung pada unsur kekerabatan yang diterapkan dalam masyarakat adat dan menjadi penentu kedudukan seseorang dalam adat. Masyarakat adat Mandailing dengan sistem kekerabatan patrilineal menerapkan sistem kewarisan hanya pada anak laki-laki saja dan sifatnya hanya hibah bagi perempuan atau waris bila terdapat wasiat sebelumnya. Penelitian menggunakan yudisial empiris dan metode deskriptif analitik dengan metode penelitian observasi dan wawancara terhadap Ketua Pardomuan Muslim Sumatera Utara (PMSU) dan juga responden utama demi mendapatkan kesimpulan secara umum. Responden pada masyarakat Mandailing perantauan Kota Palangka Raya yang tergabung dalam PMSU Kota Palangka Raya menerapkan hukum waris Islam, sehingga sistem patrilineal tidak berlaku bagi masyarakat adat Mandailing perantauan dan harta tidak diberikan pada anak laki-laki saja, namun anak perempuan mendapatkan bagian sesuai dengan perhitungan hukum waris Islam, walaupun terdapat fakta satu keluarga responden yang melimpahkan harta warisan untuk dikelola oleh anak laki-laki kedua dari tujuh bersaudara dan dipergunakan demi kepentingan semuanya, dan pelimpahan itu diawali dengan pembagian waris secara hukum Islam. Akhirnya implementasi hukum waris adat pada suku adat Mandailing perantauan tetaplah didasari hukum waris Islam. Pengaruh Islam yang melekat pada masyarakat adat Mandailing perantauan menjadi faktor utama penentu keputusan mereka dalam mengambil aturan Islam dalam sistem warisnya.
\end{abstract}

Kata Kunci: Hukum Waris dan Mandailing Perantauan

\begin{abstract}
The implementation of customary inheritance law in Indonesia is very dependent on the defeat applied in indigenous peoples and determines one's position in adat. The Mandailing indigenous community with a patrilineal kinship system applies a system of inheritance only to boys and is only a gift for women or inheritance if a will is available beforehand. The study uses empirical judicial and analytical descriptive methods with observational research methods and interviews with the Chairperson of North Sumatra
\end{abstract}


Muslim Pardomuan (PMSU) and also the main respondents to reach general conclusions. Responding to the Mandailing community per supervision of Palangka Raya City which is incorporated in the Palangkaraya City PMSU applies Islamic inheritance law so that the patrilineal system does not apply to Mandailing indigenous people per supervision and assets are not given only to boys, but daughters of Islamic inheritance, although including the fact that one respondent's family gave up the inheritance to be managed by the sons of seven siblings and used it for the benefit of all, and the delegation began with the distribution of inheritance by Islamic law. Finally, the implementation of customary inheritance law in Mandailing customary tribe per monitoring is still based on Islamic inheritance law. The influence of Islam inherent in the Mandailing indigenous people per the main factor determining their decision in taking Islamic rules in their inheritance system.

\section{Keyword: Inheritance Law and Mandailing Customary}

\section{A. PENDAHULUAN}

Indonesia merupakan suatu Negara yang memiliki khas berupa suku, agama, bahasa dan budaya yang beraneka ragam. Memiliki luas wilayah $1.904 .569 \mathrm{kmpersegi}^{1}$, dan sebagai kepulauan terluas di dunia dengan lebih dari 100 ribu $\mathrm{km}^{2}$ serta pulau Kalimantan termasuk dalam lima (5) pulau besar yang terkenal di Indonesia selain Pulau Papua, Pulau Sumatera, Pulau Sulawesi, dan Pulau Jawa. ${ }^{2}$

Keanekaragaman suku dan budaya (adat) yang ada di Indonesia membawa pada ragamnya norma yang melekat padanya dan menjadi acuan bagi setiap masyarakat untuk menjalankan norma tersebut dalam setiap kehidupannya. Soepomo menyatakan bahwa hukum adat adalah hukum tidak tertulis dalam tertuang dalam peraturan legislatif yang meliputi peraturan hidup, walaupun keberadaan peraturan tersebut tidak ditetapkan penguasa (yang berwajib), namun dipatuhi masyarakat atas dasar yakin bahwa aturan tersebut memiliki kekuatan hukum. ${ }^{3}$ Namun dipahami bahwa hukum adat juga memiliki sifat dinamis sehingga keberadaannya dapat mengalami perubahan dengan beragam adaptasi di tengah-tengah masyarakat.

\footnotetext{
${ }^{1}$ Mokhammad, 10 Pulau Terbesar di Indonesia Beserta Luas Wilayahnya (+Gambar), www.ilmufakta.com, 2018 Diakses tanggal 20 Februari 2019.

${ }^{2}$ Zakky, Seratus Pulau Terbesar di Dunia Beserta Letak Negara dan Luas Wilayahnya, www.zonareferensi.com, 2018, Diakses tanggal 20 Februari 2019.

${ }^{3}$ Soerojo Wignjodipoero, Pengantar dan Asas-asas Hukum Adat, (Jakarta: Toko Gunung Agung, 1996), hlm. 14.
} 
TAHKIM, Jurnal Peradaban dan Hukum Islam. Vol.3 No.2 (0ktober, 2020) | ISSN : 2597-7962

Masyarakat adat yang tersebar di Indonesia memiliki khas terutama dalam sistem kekerabatan serta kewarisan, baik keberadaannya masih alami di wilayah adat atau yang merantau dan menyebar di seluruh wilayah Indonesia. Sistem kewarisan erat dengan kekerabatan yang berlaku di masyarakat karena keberadaan ahli waris ditentukan berdasarkan kedudukan seseorang dalam sistem kekerabatannya. Adapun sistem kekerabatan masyarakat adat yang ada di Indonesia meliputi tiga (3) sistem kekerabatan, yaitu: patrilineal, matrilineal, dan parental-bilateral.

1. Sistem Patrilineal

Sistem yang mengambil garis keturunan dari atas yang dilakukan oleh anggotaanggota dalam suatu masyarakat tertentu. Keturunan dari atas tersebut melalui garis bapak, bapak dari bapak dan seterusnya berdasarkan jalur ke atas, sampai pada akhirnya ditemukan laki-laki yang disebut sebagai kakek moyang dari keturunan tersebut. Berdasarkan sistem ini kedudukan laki-laki menjadi penting dan dianggap utama dibandingkan kedudukan perempuan, terutama dalam hal pewarisan.

2. Sistem Matrilineal

Sistem yang mengambil garis keturunan dari atas yang dilakukan oleh anggotaanggota dalam suatu masyarakat tertentu. Keturunan dari atas tersebut melalui garis ibu, ibu dari ibu dan seterusnya berdasarkan jalur ke atas, sampai pada akhirnya ditemukan perempuan yang disebut sebagai nenek moyang dari keturunan tersebut. Berdasarkan sistem ini maka keluarga dari pihak ibu, anak-anak akan masuk ke kelaurga ibu, begitu juga dalam hal mewarisi juga dari kalangan garis ibu. Hal ini menjadikan kedudukan perempuan lebih utama dibandingan dengan kedudukan laki-laki.

\section{Sistem Parental-Bilateral}

Sistem yang mengambil garis keturunan dari atas yang dilakukan oleh anggotaanggota dalam suatu masyarakat tertentu. Keturunan dari atas tersebut melalui garis bapak serta ibu, terus ke atas sehingga ditemukan baik laki-laki dan perempuan sebagai nenek-kakek moyangnya. Keduanya memiliki kedudukan yang sama dalam 
TAHKIM, Jurnal Peradaban dan Hukum Islam. Vol.3 No.2 (0ktober, 2020) | ISSN : $2597-7962$

sistem ini, sehingga keduanya memiliki keutamaan yang sama tanpa adanya pembedaan. Semua anak, baik laki-laki atau perempuan memiliki hak yang sama atas harta peninggalan kedua orangtuanya. ${ }^{4}$

Pengakuan terhadap waris dapat diterima masyarakat Indonesia selama mencakup pada hukum waris perdata, hukum waris Islam, dan hukum waris adat. ${ }^{5}$ Dilengkapi dengan pernyataan Van Vollenhoven yang membagi lingkungan hukum adat di Indonesia menjadi 19 wilayah, yaitu Aceh, Tanah gayo-Alas dan Batak, Minangkabau, Sumatera Selatan, Melayu, Bangka dan Belitung, Kalimantan (Dayak), Minahasa, Gorontalo,Toraja, Sulawesi Selatan, Kepulauan Ternate, Maluku-Ambon, Irian, Kepulauan Timor, Bali dan Lombok, Jawa Tengah dan Timur, Swapraja Solo dan Yogyakarta, dan Jawa Barat. ${ }^{6}$

Adapun sistem kekerabatan yang dianut dalam masyarakat Indonesia berdasarkan pada faktor genealogis, yaitu kesatuan hukum dengan terikatnya seluruh anggotanya sebagai satu kesatuan karena kesatuan hukum dengan asumsi berasal dari moyang yang satu. Sehingga dapat disimpulkan bahwa sistem kekerabatan sangat dipengaruhi garis keturunan dan mengikuti kesatuan hukum adat.

Maka pada masyarakat adat Mandailing memiliki konsep sistem kekerabatan patrilineal dengan garis keturunan ayah yang paling kuat. Hal ini berpengaruh pula dalam menentukan hak waris pada ahli waris. Dengan kedudukan garis keturunan patrilineal yang mengedepankan anak lak-laki, maka semua waris berdasarkan adat Batak hanya diberikan pada anak-anak laki-laki saja, dengan kedudukannya sebagai anak laki-laki tertua, anak laki-laki termuda, atau anak laki-laki sulung dan bungsu. Disebutkan oleh Imam Sudiyat bahwa pembagian warisan suku Mandailing terbagi pada 3 hal, yaitu anak lak-laki tertua, termuda dan anak laki-laki sulung dan bungsu. ${ }^{7}$

${ }^{4}$ I.G.N. Sugangga. Hukum Waris Adat. (Semarang, Badan Penerbit: Universitas Diponegoro, 1995, hlm. 13-15. Lihat dalam Hilman Hadikusuma. Pengantar Ilmu Hukum Adat Indonesia, Bandung: Penerbit Mandar Maju, 2003). hlm. 108-109. Lihat dalam I Gede A. B. Wiranata. Hukum Adat Indonesia, Perkembangannya dari Masa ke Masa. (Bandung: PT. Citra Aditya Bakti, 2003). hlm. 113.

${ }^{5}$ Titik Triwulan Tutik, Hukum Perdata dalam Sistem Hukum Nasional. (Jakarta: Kencana Prenada Media Group, 2008), Cet. Pertama, hlm. 253.

${ }^{6}$ Soerojo Wignjodipoero. Pengantar dan Asas-Asas Hukum Adat. .... hlm 14.

${ }^{7}$ Imam Sudiyat. Hukum Adat Sketsa Asas. (Yogyakarta: Liberty Yogyakarta, 1978). hlm. 83. 
Berdasarkan hal tersebut maka kedudukan perempuan tidak dapat memiliki kesempatan mendapatkan waris kecuali sifatnya adalah hibah atau pemberian. Berbeda bila anak perempuan telah menikah dan keluar dari kerabat ayahnya ataupun tidak keluar dari kerabat ayahnya, maka perempuan tersebut tidak berhak menuntut hak waris tanpa wasiat. Artinya sama saja bagi anak perempuan dalam suku Mandailing tidak akan mendapatkan waris kecuali sebagai hibah atau pemberian. ${ }^{8}$

Adapun hukum waris adalah suatu hukum tentang meneruskanharta kekayaan dari suatu generasi kepada keturunannya, ${ }^{9}$ Van Dijk juga mengungkapkan bahwa hukum waris adat adalah suatu kompleks kaidah-kaidah yang mengatur proses penerusan dan pengoperan daripada harta, baik materiil atau immaterial dari generasi ke generasi berikutnya. Dan berkaitan dengan pewarisan tidak selalu harus karena adanya kematian, dengan hakekat yang menjadi ahli waris adalah angkatan yang lebih muda dengan suatu kaidah hukum waris yang dijiwai sikap hidup kekeluargaan, dan pembagian harta peninggalan tidak dapat dilakukan berdasarkan ilmu hitung melainkan menurut kegunaan. ${ }^{10}$ Lebih luas makna hukum waris adat menurut Ter Haar menyatakan bahwa hukum waris adat adalah aturan-aturan hukum yang mengatur cara bagaimana dari abad ke abad penerusan dan peralihan dari harta kekayaan yang berwujud dan tidak berwujud dari generasi pada generasi berikut. ${ }^{11}$

Istilah-istilah dalam hal kewarisan dalam hukum adat mencakup empat (4) unsur pokok, yaitu: pewaris; harta waris; ahli waris; dan penerusan dan pengalihan harta waris. ${ }^{12}$ Ada juga yang menjelaskan dengan terdapatnya tiga (3) unsur yaitu: proses pengoperan atau hibah atau penerusan atau warisan; harta benda materil dan immateriail; dan satu generasi ke generasi selanjutnya. ${ }^{13}$

\footnotetext{
${ }^{8}$ Mizuki Ashiya. Hukum Adat Perkawinan dan Waris Adat Mandailing. 2011. http://mizukiashyiyakawaii.blogspot.com Diakses tanggal 20 Februari 2019.

${ }^{9}$ Beni Ahmad Saebani, dkk. Perbandingan Hukum Perdata. (Bandung: CV Pustaka Setia, 2016). hlm. 297.

${ }^{10}$ Titik Triwulan Tutik. Hukum Perdata dalam ... hlm. 296.

${ }^{11}$ Beni Ahmad Saebani, dkk. Perbandingan... hlm. 296.

${ }^{12}$ Ibid.

${ }^{13}$ Titik Triwulan Tutik, Hukum Perdata dalam ... hlm. 297.
} 
TAHKIM, Jurnal Peradaban dan Hukum Islam. Vol.3 No.2 (0ktober, 2020) | ISSN : $2597-7962$

1. Pewaris adalah orang yang meneruskan harta peninggalan atau orang yang memiliki harta warisan,

2. Ahli waris adalah istilah yang menunjukkan orang yang berhak menerima atau mendapatkan harta warisan.

3. Cara pengalihan atau penerusan harta warisan dapat dilakukan sebelum maupun setelah wafat pewaris. ${ }^{14}$ Adapun sifat dari hukum waris adat diantaranya:

a. Harta warisan sistem hukum adat tidak berupa kesatuan yang bisa dinilai harganya, atau tidak dapat terbagi, kalaupun dapat terbagi maka ditentukan menurut jenis macamnya dan kepentingan para ahli waris,

b. Kewarisan dalam hukum adat tidak mengenal asas legitieme portie (bagian mutlak),

c. Kewarisan dalam hukum adat tidak mengenal hak bagi ahli waris untuk sewaktu-waktu dapat menuntut agar harta warisan segera dibagikan. ${ }^{15}$

Berdasarkan ketentuan tentang fungsi harta kekayaan maka hukum waris mengenal dua macam harta peninggalan, yaitu harta yang dapat dibagi seperti pada adat Jawa. Orangtua dapat membagi kekayaan ketika masih hidup dan dapat dibagi pula ketika orangtua telah meninggal. Harta yang tidak dapat dibagi berupa harta pusaka yang dimiliki kompleks famili, ini berlaku pada masyarakat yang bersusun unilateral atau bersistem kekerabatan patrilineal seperti Batak, Tapanuli. Berlaku pula pada masyarakat matrilineal seperti Minangkabau dan lain sebagainya. Harta yang tidak dapat dibagi lainnya bila hanya ada seorang anak saja yang mewarisi namun dia memiliki kewajiban untuk memelihara saudara-saudaranya, ini berlaku pada masyarakat Bali dan Lampung. Harta yang tidak dapat terbagi dikenal dua macam, yaitu pertama: harta peninggalan mayorat (suatu sistem kewarisan dengan anak tertua sebagai ahli warisnya, bisa laki-laki ataupun perempuan), kedua: harta peninggalan kolektif (suatu sistem kewarisan dengan harta pusaka dimiliki bersama oleh keluarga atau famili). ${ }^{16}$

\footnotetext{
${ }^{14}$ Beni Ahmad Saebani, dkk. Perbandingan... hlm. 296.

${ }^{15}$ Ibid,. hlm.. 297.

${ }^{16}$ Titik Triwulan Tutik, Hukum Perdata dalam ... hlm. 298-300.
} 
TAHKIM, Jurnal Peradaban dan Hukum Islam. Vol.3 No.2 (0ktober, 2020) | ISSN : 2597-7962

Berdasarakan hal diatas ditentukan rumusan masalah penelitian ini sebagai berikut:

1. Bagaimanakah perkembangan hukum waris adat Mandailing perantauan yang tergabung dalam PMSU Kota Palangka Raya?

2. Bagaimanakah pelaksanaan hukum waris adat Mandailing perantauan yang tergabung dalam PMSU Kota Palangka Raya?

\section{B. METODE PENELITIAN}

Adapun jenis penelitian yang digunakan peneliti adalah penelitian hukum empiris yang bersifat deskriptif analitis. Dengan beberapa sumber data yang digunakan meliputi:

1. Data Primer, yakni data yang didapatkan secara langsung dari sumber yang diperoleh berdasarkan wawancara, observasi baik secara partisipasi atau non partisipasi.

2. Responden. Adapun responden pada penelitian ini yaitu masyarakat AngkolaMandailing yang tergabung dalam Pardomuan Mandailing Kota Palangka dan telah menetap di Kota Palangka Raya akibat merantau. Penarikan sampel peneliti lakukan dengan menentukan jumlah sampel sesuai pada data anggota Pardomuan Mandailing Kota Palangka Raya yang memiliki fakta telah meninggalnya kepala keluarga (laki-laki atau suami). Metode Purposive Sampling dengan ketentuan yang peneliti tentukan sendiri dari keseluruhan populasi masyarakat adat AngkolaMandailing di Kota Palangka Raya.

3. Informan. Adapun informan sebagai pelengkap data penelitian ini maka peneliti memerlukan informasi tambahan dari narasumber lainnya yang dianggap mengetahui dan memiliki data terhadap objek peneitian yang terdiri dari:

a. Ketua Pardomuan Muslim Sumatra Utara Kota Palangka Raya

b. Tokoh Adat yang dituakan di daerah Kota Palangka Raya, yang tergabung dalam Pardomuan Mandailing Sumatra Utara Kota Palangka Raya 
4. Data Sekunder, yakni data yang didapatkan secara langsung dan tidak langsung berupa tiga (3) bahan hukum dengan uraian sebagai berikut:

a. Bahan Hukum Primer

Adapun bahan hukum primer adalah bahan hukum dengan kekuatan mengikat bagi landasan utama dalam rangka penelitian. Bahan tersebut peneliti fokuskan pada Undang-undang (UU) yang berkaitan dengan hukum keluarga, hukum waris Islam dan adat.

b. Bahan Hukum Sekunder

Adapun bahan hukum sekunder adalah bahan hukum yang dapat memperkuat bahan hukum primer dengan penjelasan dan informasi yang diperoleh dari hasilhasil penelitian para pakar hukum, jurnal-jurnal, buku teks seputar hukum, dan dokumen lainnya yang menunjang penelitian ini.

c. Bahan Hukum Tersier

Adapun bahan hukum tersier berkedudukan sebagai penunjang yang memperjelas dari dua bahan hukum lainnya, seperti kamus hukum, kamus bahasa, ensiklopedia, sumber data elektronik berupa internet dan lain sebagainya yang membantu dalam perolehan data.

Adapun metode pengumpulan data yang peneliti gunakan yaitu dengan metode penelitian kepustakaan (library research) dan lapangan (field research), serta ditambah dengan analisis langsung terhadap informan dengan menggunakan pedoman analisis yang peneliti siapkan. Hal tersebut bertujuan untuk mengembangkan semua data penelitian yang telah diperoleh.

\section{PEMBAHASAN}

Mandailing sebagai sebuat nama wilayah khas muslim di Tapanuli Selatan Sumatera Utara memiliki pengertian sebagai mande hilang yang artinya ibu yang hilang. Pengertian lainnya sebagai mandahilang yang artinya ibu yang mengungsi, atau manda holing yang berarti nama suatu kerajaan yang wilayahnya mencakup Portibi di gunung Tua Padang Lawas hingga Piu Delhi di Mandailing. Selain itu dikenal juga dengan kata mandalay yang berarti nama dari suatu kota besar di wilayah Birma, 
terutama di Birma Utara terdapat sebuah kota kebudayaan atau pusat peradaban dan pemerintahan yang disebut sebagai mandalay. Pengertian hilang di sini yakni pada saat pengaruh bangsa Melayu mulai masuk pada wilayah ini, kondisinya tidak ditemukan lagi orang-orang atau ibu tadi di wilayah tersebut karena melakukan pindah ke tempat lain, sehingga orang suku Bangsa Melayu menyebutnya mandala hilang yang pada akhirnya berubah menjadi kata mandailing. ${ }^{17}$

Mandailing memiliki monografi yang ditentukan oleh masyarakat adat yang berbeda dengan batasan yang ditentukan oleh pemerintah. Letaknya di Kabupaten Mandailing Natal berada di tengah Pulau Sumatera sepanjang jalan raya lintas Sumatera kurang lebih $40 \mathrm{Km}$ dari Padangsidimpuan ke Selatan dan kurang lebih $150 \mathrm{Km}$ dari Bukit Tinggi ke utara, dengan batasan wilayah sebelah utara dengan Angkola, batasan wilayah sebelah barat dengan Pesisir, batasan wilayah selatan dengan Minangkabau, dan batasan sebelah timur dengan Padanglawas. ${ }^{18}$ Sedangkan batasan wilayah yang berasal dari ketentuan pemerintah tercakup dalam UU RI Nomor 12 Tahun 1998 yang menetapkan bahwa wilayah Kabupaten Daerah Tingkat II Mandailing Natal memiliki batasan di sebelah utara dengan Kecamatan Padangsidempuan Barat, Kecamatan Siasis, Kecamatan Batang Angkola, Kecamatan Sosopan, Kecamatan Barumun, dan Kecamatan Sosa Kabupaten Daerah Tingkat II Tapanuli Selatan. Sebelah timur dan selatan berbatasan dengan Provinsi Daerah Tingkat I Sumatera Barat. Sebelah barat berbatasan dengan Samudera Hindia. ${ }^{19}$

Kabupaten Mandailing Natal memiliki luas sekitar 662.070 hektar atau 6.620,70 kilometer persegi dengan jumlah penduduk sebanyak 403.894 jiwa. Berada pada urutan teratas atau terbanyak yaitu terletak pada Kecamatan Penyabungan yakni sebanyak 77.417 jiwa, Kecamatan Siabu sebanyak 47.273 jiwa, dan Kecamatan Natal sebanyak

\footnotetext{
${ }^{17}$ Pangaduan Lubis. Asal Usul Marga-marga di Mandailing (Lubis, Nasution, Batubara, Rangkuti, Parinduri, Dailae, Matondang, Pulungan). (Medan: Pustaka Widiasarana (Kelompok Humaniora-POKMAS Mandiri, 2010). hlm. 11-13, 15.

${ }^{18}$ Pandapotan Nasution. Adat Budaya Mandailing dalam Tantangan Zaman. (Medan: Penerbit FORKALA-SU, 2006). hlm. 5.

${ }^{19}$ Undang-undang Nomor 12 Tahun 1998 Tentang Penetapan Batas Wilayah Kabupaten Daerah Tingkat II Mandailing Natal.
} 
TAHKIM, Jurnal Peradaban dan Hukum Islam. Vol.3 No.2 (0ktober, 2020) | ISSN : $2597-7962$

27.307 jiwa. ${ }^{20}$ Adapun mata pencaharian masyarakat Mandailing pada umumnya adalah petani, sebagian besar masyarakatnya sebagai petani sawah, petani perkebunan dengan ragam tanaman yang ditanam seperti karet, kopi, kulit manis, dan cengkeh. ${ }^{21}$

Kehidupan beragama pada masyarakat Mandailing kental dengan agama Islam, dengan hampir mayoritas penduduknya Muslim maka memiliki pengaruh dalam menentukan aturan-aturan yang diterapkan di tengah-tengah masyarakat Mandailing, karena erat hubungannya pada posisi Mandailing yang berbatasan dengan bagian selatan dari Propinsi Sumatera Barat yang berbatasan dengan Minangkabau, dimana sangat diketahui Minangkabau adalah wilayah adat yang memiliki pemahaman Islam kuat dan kental diterapkan di masyarakat. ${ }^{22}$

Wilayah Mandailing terbagi menjadi dua wilayah yaitu Mandailing Godang dan Mandailing Julu. Pada masing-masing wilayah tersebut berkembang pula jenis etnik yang berbeda. Mandailing Godang pada bagian utara Penyabungan yang diawali dari Sihepeng hingga Maga sebelah selatan, serta daerah Batang Natal sampai Muarasoma dan Muara Parlampungan sebelah Barat didominasi Marga Nasution. Sedangkan Mandailing Julu yang berada di sebelah utara Kotanopan di mulai dari Laru dan Tambangan hingga Pakantan dan Hutana Godang di sebelah selatan, dengan marga yang mendominasi adalah Marga Lubis. ${ }^{23}$

Adapun PMSU Kota Palangka Raya sebagai wadah berkumpulnya masyarakat batak perantauan, maka PMSU mengambil andil untuk tetap menjaga kekerabatan atau kedekatan antara para perantau di kota yang sama. Keberadaan PMSU Kota Palangka Raya sejak 1976 ini sudah beberapa kali pergantian ketua, pertama Bapak M.O. Hasibuan (almarhum), dan kedua Bapak Drs. H. Hasanuddin Nasution. Jumlah anggota PMSU di Kota Palangka Raya kurang lebih 57 kepala keluarga, dengan latar belakang pendidikan beragam baik S1, dan S2. Dengan jumlah yang PNS sebanyak 33 orang dan

\footnotetext{
${ }^{20}$ BPS Mandailing Natal.

${ }^{21}$ Pandapotan Nasution. Adat Budaya Mandailing ... hlm. 6.

${ }^{22}$ Ensiklopedia Nasional Indonesia Jilid 10. (Jakarta: PT. Delta Pamungkas, 1997), hlm. 125. Hal ini juga diperkuat berdasarkan wawancara dengan Bapak Hassanuddin, selaku Ketua PMSU Kota Palangka Raya, tanggal 20 Februari 2019 di Kota Palangka Raya.

${ }^{23}$ Pandapotan Nasution. Adat Budaya Mandailing ... hlm. 216.
} 
TAHKIM, Jurnal Peradaban dan Hukum Islam. Vol.3 No.2 (0ktober, 2020) | ISSN : $2597-7962$

swasta sebanyak 24 orang dengan riwayat pendidikan MI/SD, SMP/MTsN, SMA/MA. ${ }^{24}$

Salah satu budaya masyarakat Suku Adat Mandailing adalah merantau, dan pantang bagi mereka untuk pulang ke kampung halaman apabila belum berhasil di perantauan. Merantau adalah budaya yang telah lama dilakukan oleh masyarakat adat Mandailing dan menyebar hampir di seluruh wilayah Indonesia. Lamanya merantau tidak terukur waktu, selama apapun tidak menjadi problem karena bagi yang merantau mereka telah mencari pola kehidupan baru di wilayah baru dan melestarikan keberadaan keluarga hingga beberapa keturunan di wilayah perantauan. Sehingga pada akhirnya terdapat kepala keluarga yang meninggal, maka tidak sedikit pelaksanaan beberapa aturan adat juga kian mengalami perkembangan.

Adapun sistem kekerabatan yang berlaku di masyarakat adat manapun adalah patrilineal, matrilineal dan parental-bilateral. Bagi masyarakat adat Mandailing perantauan yang tergabung dalam PMSU Kota Palangka Raya dengan kondisi kepala keluarga yang telah meninggal ada dua keluarga, masing-masing keluarga tersebut dalam implementasi kewarisan dalam keluarga mereka tidak cenderung menggunakan sistem patrilineal, justru ke arah parental-bilateral dimana semua anak dianggap memiliki hak yang sama untuk memperoleh waris, hal ini menunjukkan kecenderungan menggunakan konsep Islam dalam menentukan waris. Dengan begitu pemahaman kekerabatan patrilineal tidak berlaku pada masyarakat adat Mandailing perantauan yang ada di Kota Palangka Raya. ${ }^{25}$

Penerusan dan peralihan harta kekayaan dapat berlaku sejak pewaris masih hidup atau setelah pewaris meninggal dunia. ${ }^{26}$ Dalam hukum adat pada umumnya, proses pewarisan dapat berlangsung sebelum si pewaris meninggal, yaitu hibah dan wasiat. Berbeda lagi dengan halnya harta yang berpindah tangan dengan cara warisan. Disebut harta warisan jika perpindahan harta tersebut terjadi setelah pemilik harta

\footnotetext{
${ }^{24}$ Wawancara dengan Bapak M. Siregar, selaku tokoh PMSU Kota Palangka Raya, tanggal 20 Februari 2019 di Kota Palangka Raya. Ditambah dengan arsip PMSU Kota Palangka Raya.

${ }^{25}$ Wawancara dengan Bapak Hasanuddin. Selaku Ketua PMSU Kota Palangka Raya, tanggal 20 Februari 2019 di Kota Palangka Raya

${ }^{26}$ Anton Budiarto. 2010. Materi Hukum Waris Adat. http:/Antonbudiarto.Wordpress.Com Diakses tanggal 20 Februari 2019.
} 
meninggal, dan cara membagi harta peninggalannya harus dilakukan menurut petunjukpetunjuk yang ditentukan. ${ }^{27}$

Sebelum harta peninggalan menjadi hak ahli waris, lebih dahulu harus diperhatikan berbagai hak yang menyangkut harta peninggalan itu sebab pewaris pada waktu hidupnya mungkin memiliki hutang yang belum terbayar, meninggalkan suatu pesan (wasiat) yang menyangkut harta peninggalan dan lain sebagainya. Hak yang berhubungan dengan harta peninggalan itu secara tertib seperti mengeluarkan biaya penyelenggaraan jenazah, membayarkan hutang pewaris (mayit), dan memberikan hak

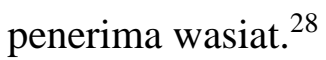

Masyarakat adat Mandailing perantauan dalam implementasi hukum warisnya menggunakan aturan Islam yakni sesuai dengan ketentuan Al Qur'an dan Hadist. Adapun beberapa tahapan yang dilakukan oleh masyarakat adat Mandailing dalam pelaksanaan kewarisan dalam keluarga mereka sebagai berikut: pihak keluarga mengeluarkan hak-hak yang berkaitan dengan harta peninggalan; pihak keluarga merujuk pada ajaran Islam dalam membagi waris; menentukan siapa ahli waris dari pihak keluarga yang ditinggalkan, dan menentukan besarnya jumlah waris, mengkomunikasikan kepada semua yang berkedudukan sebagai ahli waris dan menjelaskan pembagiannya dan memberikan bagian warisnya.

Selanjutnya setelah waris telah dijelaskan dan dibagi, pihak saudara-saudara perempuan menyerahkan pada anak laki-laki tertua dari semua anak perempuan untuk mengelola harta warisan, untuk digunakan sesuai keperluan semua saudara-saudara. Sehingga dalam hal ini anak perempuan memiliki hak dan kesempatan yang sama dalam memperoleh harta waris. Ini tentu berbeda kalau diterapkan hukum waris adat dengan jalur patrilineal yang menjadikan perempuan tidak berhak mendapatkan waris kecuali hibat dan adanya wasiat terlebih dahulu.

Sehingga anak perempuan dan juga laki-laki terhadap harta kekayaan yang diambil manfaatnya secara bersamaan seperti rumah peninggalan dan beberapa pintu

\footnotetext{
${ }^{27}$ J. Soenik Nurlaili. Prosedur Pembagian Harta Warisan, http:/Jsoeniknurlail.Blogspot.co.id Diakses tanggal 20 Februari 2019).

${ }^{28}$ M. Hasballah Thaib. Ilmu Hukum Waris Islam, (Medan, 2012). hlm. 19.
} 
kost untuk bisa menjadi sumber pemasukan bagi seluruh keluarga dalam melanjutkan kehidupan mereka dapat dirasakan oleh semua anak baik laki-laki dan juga perempuan. Semua sepakat dan pembagian waris tetap dengan ketentuan syariat Islam, walaupun dalam implementasinya harta tetap dalam pengetahuan anak laki-laki yang dipercaya berdasarkan asas kekeluargaan. ${ }^{29}$

Perihal pembagian waris dalam adat yang tidak mengenal bagian mutlak maka dalam Islam memiliki ketentuan jelas dalam jumlah waris yang dibagikan. Dalam pelaksanaanya di adat Mandailing perantauan dibagi terlebih dahulu berdasarkan hukum Islam, kemudian dapat dimanfaatkan secara bersamaan sesuai dengan kegunaan masingmasing saudaranya, terutama pada harta yang tidak dapat dibagi.

Harta menurut hukum adat ada yang mayorat dan kolektif, maka pada masyarakat adat Mandailing perantauan sebagai responden memiliki fakta ada rumah peninggalan orang tua juga beberapa pintu kost, dimana hasil penyewaan kost dimanfaatkan secara bersamaan oleh semua ahli waris tanpa ada pembagian mutlak. Maka berdasarkan hal ini pelaksanaan hukum waris adat Mandailing perantauan telah dihitung berdasarkan syariat Islam, setelahnya diserahkan pada masing-masing ahli waris mengelolanya, walaupun pada faktanya mereka tetap memberikan kepercayaan pada anak laki-laki tertua untuk mengelola harta demi kepentingan semua keluarga. Dan ada pula menjadikan rumah dan kost sebagai harta yang tidak dapat di bagi rata, hanya saja hasil rumah bisa dipakai oleh semua, dan hasil kost bisa digunakan untuk memenuhi kebutuhan seluruh anggota keluarga ahli waris.

Adapun waktu pelaksanaan pembahasan waris dalam masyarakat adat Mandailing perantauan berdasarkan keterangan responden bahwa dilakukan setelah urusan penyelenggaraan jenazah selesai dan perkumpulan di antara keluarga responden telah kembali ke kota atau ke kediaman masing-masing, hal itu dapat diukur sekitar sebulan setelah dikuburkannya jenazah. Sehingga implementasinya tidak terdesak dan terburu-buru. Karena masih memperhatikan keluarga yang berkunjung dan hadir saat

\footnotetext{
${ }^{29}$ Wawancara dengan Bapak Ali F. R. Selaku responden utama anggota PMSU Kota Palangka Raya, tanggal 20 Februari 2019 di Kota Palangka Raya.
} 
proses penyelenggaran jenazah begitu pula setelah cukup waktu untuk bisa beradaptasi dengan kondisi ditinggalkan keluarga utama. ${ }^{30}$

Sikap yang diambil oleh masyarakat adat Mandailing perantauan erat kaitannya dengan pemahaman Islam yang melekat pada kehidupan mereka. Berdasarkan hal itu maka masyarakat Mandailing perantauan sangat terbuka dalam menerima otoritas hukum Islam terhadap diri mereka, terutama dalam hal implementasi hukum waris, ini sebagaimana yang disampaikan oleh Gibb yang mengenalkan teori penerimaan otoritas hukum Islam, bahwa siapa pun yang telah mengenal Islam dan menjalankannya walaupun dia memiliki pemahaman adat sebelumnya, tapi ketika mengenal Islam dan mereka mengambil secara sepenuhnya bahwa aturan Islam sebagai aturan tertinggi yang mesti di ambil. ${ }^{31}$

Selain itu juga terdapatnya perubahan sikap dari perilaku masyarakat yang kental adatnya dan yang telah dipengaruhi Islam, sehingga secara sosiologis mengalami perubahan, bahwa hukum Islam diambil berdasarkan tingkat ketakwaan yang dimiliki masyarakat adat Mandailing perantauan dan mereka rela meninggalkan apa yang telah dipahami dalam aturan adat nenek moyang mereka sebelumnya. Sebagaimana teori evolusi yang mengenalkan adanya asumsi kemajuan budaya, yang berawal primitif kemudian karena dipengaruhi Islam sehingga mengalami perubahan dan perkembangan.

\section{SIMPULAN}

Masyarakat Mandailing perantauan yang tergabung dalam PMSU Kota Palangka Raya pada saat ini telah mengalami perkembangan dalam menerapkan sistem kewarisannya yakni dengan menerapkan hukum Islam. Meskipun secara adat pembagain waris hanya berlaku bagi anak laki-laki sedangkan bagi perempuan hanya berupa hibah, dan kalaupun waris itu diawali dengan adanya wasiat dari pewaris. Hasil penelitian menunjukkan bahwa masyarakat adat Mandailing perantauan telah

\footnotetext{
${ }^{30}$ Ibid.

${ }^{31}$ Tim Penulis, (2000) Majalah Ilmu Pengetahuan Agama, Pekanbaru: Pusat Penelitian IAIN Susqa, (Jurnal An-Nida), Nomor Edisi LXXVII Tahun XXIII, Desember 1999-Januari 2000, hlm. 40.
} 
TAHKIM, Jurnal Peradaban dan Hukum Islam. Vol.3 No.2 (0ktober, 2020) | ISSN : 2597-7962

menggunakan sistem waris Islam dan tidak lagi menerapkan sistem kewarisan yang bersifat patrilineal.

Pelaksanaan hukum waris pada masyarakat adat Mandailing disesuaikan dengan mekanisme Islam, seperti lebih dahulu harus diperhatikan berbagai hak yang menyangkut harta peninggalan itu sebab pewaris pada waktu hidupnya mungkin memiliki hutang yang belum terbayar, meninggalkan suatu pesan (wasiat) yang menyangkut harta peninggalan dan lain sebagainya. Hak yang berhubungan dengan harta peninggalan itu secara tertib seperti mengeluarkan biaya penyelenggaraan jenazah, membayarkan hutang pewaris (mayit), dan memberikan hak penerima wasiat.

\section{DAFTAR PUSTAKA}

\section{Buku:}

Ensiklopedia Nasional Indonesia Jilid 10, (1997), Jakarta: PT. Delta Pamungkas

Hilman Hadikusuma. (2003). Pengantar Ilmu Hukum Adat Indonesia. Bandung: Penerbit Mandar Maju.

Pangaduan Lubis. (2020). Asal Usul Marga-marga di Mandailing (Lubis, Nasution, Batubara, Rangkuti, Parinduri, Dailae, Matondang, Pulungan). Medan: Pustaka Widiasarana (Kelompok Humaniora-POKMAS Mandiri)

Pandapotan Nasution. (2006). Adat Budaya Mandailing dalam Tantangan Zaman. Medan: Penerbit FORKALA-SU.

Beni Ahmad Saebani, dkk. (2016). Perbandingan Hukum Perdata. Bandung: CV Pustaka Setia.

Soerojo Wignjodipoero. (1996). Pengantar dan Asas-asas Hukum Adat, Toko Gunung Agung. Jakarta.

Sugangga, I.G.N. (1995). Hukum Waris Adat. Badan Penerbit: Universitas Diponegoro. Semarang.

Hasballah Thaib. (2012). Ilmu Hukum Waris Islam. Medan. 
TAHKIM, Jurnal Peradaban dan Hukum Islam. Vol.3 No.2 (0ktober, 2020) | ISSN : 2597-7962

Tutik, Titik Triwulan. (2008). Hukum Perdata dalam Sistem Hukum Nasional. Jakarta: Kencana Prenada Media Group. Cetakan Pertama.

I Gede A. B. Wiranata. (2005). Hukum Adat Indonesia, Perkembangannya dari Masa ke Masa. Bandung: PT. Citra Aditya Bakti.

\section{Jurnal:}

Jurnal An-Nida. Majalah Ilmu Pengetahuan Agama. Pekanbaru: Pusat Penelitian IAIN Susqa. Nomor Edisi LXXVII Tahun XXIII, Desember 1999-Januari 2000.

\section{Undang-undang:}

Undang-undang Nomor 12 Tahun 1998 Tentang Penetapan Batas Wilayah Kabupaten Daerah Tingkat II Mandailing Natal.

\section{Internet:}

Anton Budiarto, 2010, Materi Hukum Waris Adat,

http:/Antonbudiarto.Wordpress.com. Diakses tanggal 20 Februari 2019.

Badan Pusat Statistik, https://www.bps.go.id/. Diakses tanggal 12 Februari 2020.

J. Soenik Nurlaili, 2013, Prosedur Pembagian Harta Warisan, http:/Jsoeniknurlail. Blogspot.co.id. Diakses tanggal 20 Februari 2019.

Mokhammad, 10 Pulau Terbesar di Indonesia Beserta Luas Wilayahnya (+Gambar), www.ilmufakta.com, 2018. Diakses tanggal 20 Februari 2019.

Mizuki Ashiya. Hukum Adat Perkawinan dan Waris Adat Mandailing. 2011. http://mizukiashyiyakawaii.blogspot.com. Diakses tanggal 20 Februari 2019.

Zakky, Seratus Pulau Terbesar di Dunia Beserta Letak Negara dan Luas Wilayahnya, www.zonareferensi.com, 2018, Diakses tanggal 20 Februari 2019. 